\title{
Study of Employee Commitment and Resource Utilization in Oil and Gas Companies in Port Harcourt, Rivers State, Nigeria
}

\author{
Maduabuchi Chinyere Emeka ${ }^{1}$, and Simeon Abel Igah $^{2}$ \\ Department of Management \\ Faculty of Business Studies \\ Ignatius Ajuru University of Education \\ Port Harcourt, Rivers State, Nigeria
}

\begin{abstract}
The objective of this research is to investigate employee commitment and resource utilization of oil companies in Port Harcourt. The correlational survey design was adopted for the study. The researchers collected ample number of sample and data, which was analyzed using statistical methods. It was found from the analyses that significant relationship existed between affective commitment and time minimization; continuous commitment and cost minimization; normative commitment and waste minimization. The study concluded that in organizational milieu where affective commitment, continuous commitment and normative commitment existed, time minimization, cost minimization and waste minimization are enhanced in oil and gas companies in Port Harcourt. Based on the study, the researchers briefed that, employees should be well paid to achieve cost minimization and where policy adherence were strongly enforced, only enacted roles and not expected roles should be expected from workers.
\end{abstract}

Keywords: Employee Commitment, Resource Utilization, Affective Commitment, Continuous Commitment, Normative Commitment, Time Minimization, Cost Minimization, Waste Minimization.

\section{INTRODUCTION}

According to CRLS GUID159E and USC Libraries an introduction of a study should encompass the study framework, out of which the various segments of the study emerge. This empirical study, Employee Commitment and Resource Utilization in Oil and Gas Companies in Port Harcourt, Rivers State, Nigeria will be looked into correlationally and through conceptual framework. This is so because the simplistic conclusion that employee commitment has or has no relationship with resource utilization may not give a true picture of the behaviors of the elements of employee commitment and resource utilization. For this reason, we will introduce the predictor variable as Employee Commitment (EC) and the criterion variable as Resource Utilization (RU) and will use, on the strength of the principle of parsimony, the operational framework structure to reveal the relationship amongst the dimensions - Affective Commitment (AC), Continuous Commitment (CC) and the Normative Commitment (NC) under the predictor variable and the measures - Time Minimization (TM), Cost Minimization (CM) and Waste Minimization (WM) under the criterion variable. An "Employee Commitment and Resource Utilization" questionnaire will be used to gather the study data from a sample of 248 workers from a population of 650 workers, extracted from Shell Petroleum Development Company (SPDC), Elf Petroleum Nigeria Limited (ELF), Chevron Nigeria Limited and ExxonMobil, Nigeria. The study will take place in Port Harcourt, Nigeria. Abstract, research objectives and research hypotheses will be laid out. SPSS, version 25 will be used to carry out both univariate and bivariate analyses. Interpretation of the bivariate analyses will be given. Summary of findings from the analyses will be presented. Conclusion of the study will be made and recommendation will be given based on the finding

\section{EMPLOYEE COMMITMENT AND RESOURCE UTILIZATION OF OIL COMPANIES CONCEPTUAL FRAMEWORK CONSTRUCT}


inferred from the research problem, two (2) major variables emerged in the study. These were the Predictor Variable and the Criterion Variable. The Predictor variable is Employee Commitment (EC), which has under it the dimensions - Affective Commitment (AC), Continuous Commitment (CC) and Normative Commitment (NC). The Criterion Variable, which is Resource Utilization (RU). The indicators of this dependent variable are: Time Minimization (TM), Cost Minimization (CM) and Waste Minimization (WM).

\section{RESEARCH OBJECTIVES}

1. To ascertain the relationship between Continuous Commitment (CC) and Resource Utilization (RU) in oil and gas companies in Port Harcourt, Rivers State, Nigeria.

2. To ascertain the relationship between Normative Commitment (NC) and Resource Utilization (RU) in oil and gas companies in Port Harcourt, Rivers State, Nigeria.

3. To ascertain the relationship between Affective Commitment (AC) and Resource Utilization (RU) in oil and gas companies in Port Harcourt, Rivers State, Nigeria.

\section{RESEARCH QUESTIONS}

The following research questions were raised to guide the study:

(1) What relationship exists between Continuous Commitment and Resource Utilization of Oil and Gas Companies in Port Harcourt, Rivers State, Nigeria?

(2) What relationship exists between Normative Commitment and Resource Utilization of Oil and Gas Companies in Port Harcourt, Rivers State, Nigeria?

(3) What relationship exists between Affective Commitment and Resource Utilization of Oil and Gas Companies in Port Harcourt, Rivers State, Nigeria?

\section{RESEARCH HYPOTHESES}

The following null hypotheses were formulated and tested at 0.05 Alpha Coefficient:

Null Hypothesis $-\mathrm{H}_{\mathrm{ol}}$ - There is no significant relationship between Continuous Commitment and Waste minimization

Null Hypothesis - $\mathrm{H}_{\mathrm{o} 2}$ - There is no significant relationship between Continuous Commitment and Cost minimization

Null Hypothesis - $\mathrm{H}_{03}$ - There is no significant relationship between Continuous Commitment and Time Minimization

Null Hypothesis - $\mathrm{H}_{04}$ - There is no significant difference in the relationship between Normative Commitment and Waste Minimization

Null Hypothesis - $\mathrm{H}_{05}$ - There is no significant relationship between Normative Commitment and Cost Minimization

Null Hypothesis - $\mathrm{H}_{\mathrm{o} 6}$ - There is no significant relationship between Normative Commitment and Time Minimization

Null Hypothesis - $\mathrm{H}_{07}-$ There is no significant difference in the relationship between Affective Commitment and Waste Minimization

Null Hypothesis $-\mathrm{H}_{08}$ - There is no significant relationship between Affective Commitment and Cost Minimization

Null Hypothesis $-\mathrm{H}_{09}$ - There is no significant relationship between Affective Commitment and Time Minimization 


\section{Employee Commitment and Resource Utilization of Oil Companies Operational Framework}

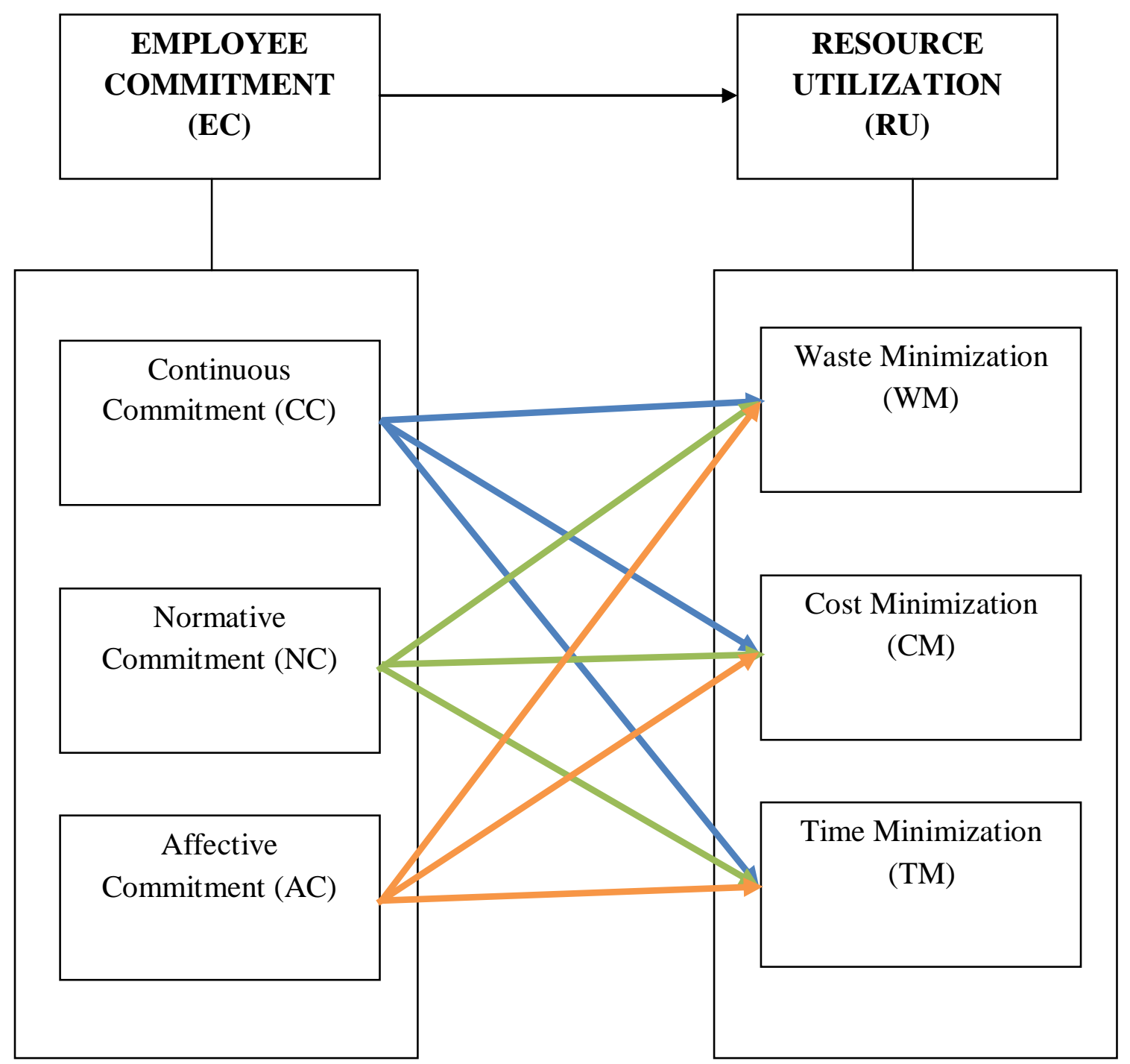

Figure 6. 1 Oil Companies Operational Framework

Source: Researchers' Operational Framework, 2022.

\section{METHODOLOGY}

This study adopted the correlational research design. The population of this study was 650 respondents which consisted of senior and junior staff in Shell Petroleum Development Company (SPDC) - 185 workers, those in Elf Petroleum Nigeria Limited (ELF) - 133 workers, Chevron Nigeria Limited - 148 workers and ExxonMobil - 184 workers, all in Rivers State. The Taro Yamane formula was used to obtain a sample size of 248. Purposive and convenient sampling techniques, by way of simple percentages of 28.41 for SPDC, 20.45 for ELF, 22.73 for Chevron and 28.41 for ExxonMobil were used to select the research respondents as samples for the population. A structured questionnaire titled "Employee Commitment and Resource Utilization" (ECRU) with a five point rating scale was designed and same was administered to the research respondents for the extraction of answers to the questions in the survey. The questions on the questionnaire were asked correlationally, using the indicators of the dimensions and measures as highlights. This was done so as to get a clear meaning of the intent of the responses of the research respondents. 248 questionnaires were administered to 248 workers and same were retrieved from them. The study had assumption tests to show the validity of the research instrument and variables. Included are the study data, which had a Cronbach's Alpha of .742; a KMO 
value of .694, Skewness and Kurtosis for normality test for the measures of the dependent variable, outlier box for the measures of the dependent variable (see tables below):

Rule: The reliable test should not be less than 0.7 for it to be acceptable

Table 7.1

Internal Consistency Table - Scale: All ITEMS

Reliability Statistics

\begin{tabular}{lll}
\hline & \multicolumn{1}{l}{ Cronbach's } \\
& $\begin{array}{l}\text { Alpha Based on } \\
\text { Cronbach's }\end{array}$ & Standardized \\
Alpha & Items & N of Items \\
\hline .742 & .763 & 9 \\
\hline
\end{tabular}

Source: Reliability Test Information, 2022

Kaiser- Meyer- Oklin and Bartlett's Test of Factorability and Sphericity Table

Table 7.2 The result of the KMO test should not be less than 0.6 for it to be acceptable.

\begin{tabular}{lll} 
KMO and Bartlett's Test & \\
\hline Kaiser-Meyer-Olkin Measure of Sampling Adequacy. & .694 \\
Bartlett's Test of Sphericity & Approx. Chi-Square & 1125.537 \\
& Df & 36 \\
& Sig. & .000 \\
\hline
\end{tabular}

Source: Test of Factorability and Sphericity, 2022

Table 7.3 NORMALITY TEST FOR THE CRITERION VARIABLES

Rule: The Skewness and Kurtosis of each criterion variable should fall within -1 to +1 and -2 to +2 , respectively

Descriptives

\begin{tabular}{|c|c|c|c|}
\hline & & Statistic & Std. Error \\
\hline \multirow{13}{*}{$\begin{array}{l}\text { Dependent Variable Time } \\
\text { Minimization }\end{array}$} & Mean & 18.64 & .291 \\
\hline & 95\% Confidence Interval for Lower Bound & 18.07 & \\
\hline & Upper Bound & 19.21 & \\
\hline & $5 \%$ Trimmed Mean & 18.89 & \\
\hline & Median & 18.00 & \\
\hline & Variance & 21.016 & \\
\hline & Std. Deviation & 4.584 & \\
\hline & Minimum & 6 & \\
\hline & Maximum & 27 & \\
\hline & Range & 21 & \\
\hline & Interquartile Range & 5 & \\
\hline & Skewness & -.738 & .155 \\
\hline & Kurtosis & .582 & .308 \\
\hline \multirow{3}{*}{$\begin{array}{l}\text { Dependent Variable Cost } \\
\text { Minimization }\end{array}$} & Mean & 22.55 & .321 \\
\hline & 95\% Confidence Interval for Lower Bound & 21.92 & \\
\hline & Upper Bound & 23.18 & \\
\hline
\end{tabular}


International Journal of Advances in Scientific Research and Engineering (ijasre), Vol 8 (2), February -2022

\begin{tabular}{|c|c|c|c|}
\hline & 5\% Trimmed Mean & \multicolumn{2}{|l|}{23.00} \\
\hline & Median & \multicolumn{2}{|l|}{23.00} \\
\hline & Variance & \multicolumn{2}{|l|}{25.568} \\
\hline & Std. Deviation & \multicolumn{2}{|l|}{5.056} \\
\hline & Minimum & \multicolumn{2}{|l|}{7} \\
\hline & Maximum & \multicolumn{2}{|l|}{30} \\
\hline & $\overline{\text { Range }}$ & \multicolumn{2}{|l|}{23} \\
\hline & Interquartile Range & \multicolumn{2}{|l|}{5} \\
\hline & Skewness & -1.385 & .155 \\
\hline & Kurtosis & 1.651 & .308 \\
\hline \multirow{13}{*}{$\begin{array}{l}\text { Dependent Variable Waste } \\
\text { Minimization }\end{array}$} & Mean & 18.60 & .299 \\
\hline & $95 \%$ Confidence Interval for Lower Bound & \multicolumn{2}{|l|}{18.01} \\
\hline & Upper Bound & \multicolumn{2}{|l|}{19.19} \\
\hline & $5 \%$ Trimmed Mean & \multicolumn{2}{|l|}{18.81} \\
\hline & Median & \multicolumn{2}{|l|}{18.00} \\
\hline & Variance & \multicolumn{2}{|l|}{22.136} \\
\hline & Std. Deviation & \multicolumn{2}{|l|}{4.705} \\
\hline & Minimum & \multicolumn{2}{|l|}{6} \\
\hline & Maximum & \multicolumn{2}{|l|}{28} \\
\hline & Range & \multicolumn{2}{|l|}{22} \\
\hline & Interquartile Range & \multicolumn{2}{|l|}{6} \\
\hline & Skewness & -.543 & .155 \\
\hline & Kurtosis & .374 & .308 \\
\hline
\end{tabular}

Source: Normality Test, 2022

Test for outliers for Time Minimization

Rule: If no outliers in the box, it is acceptable

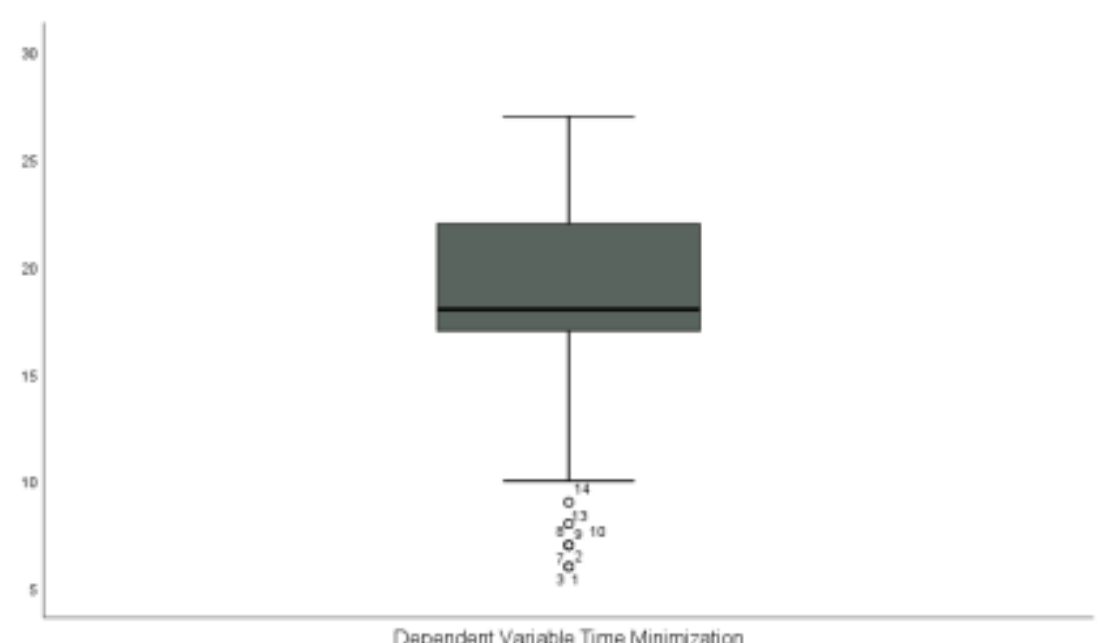

Dependent Variable Time Minimization

Figure 7.1

Source: Assumption Testing Result, 2022

Test for outliers for Cost Minimization 


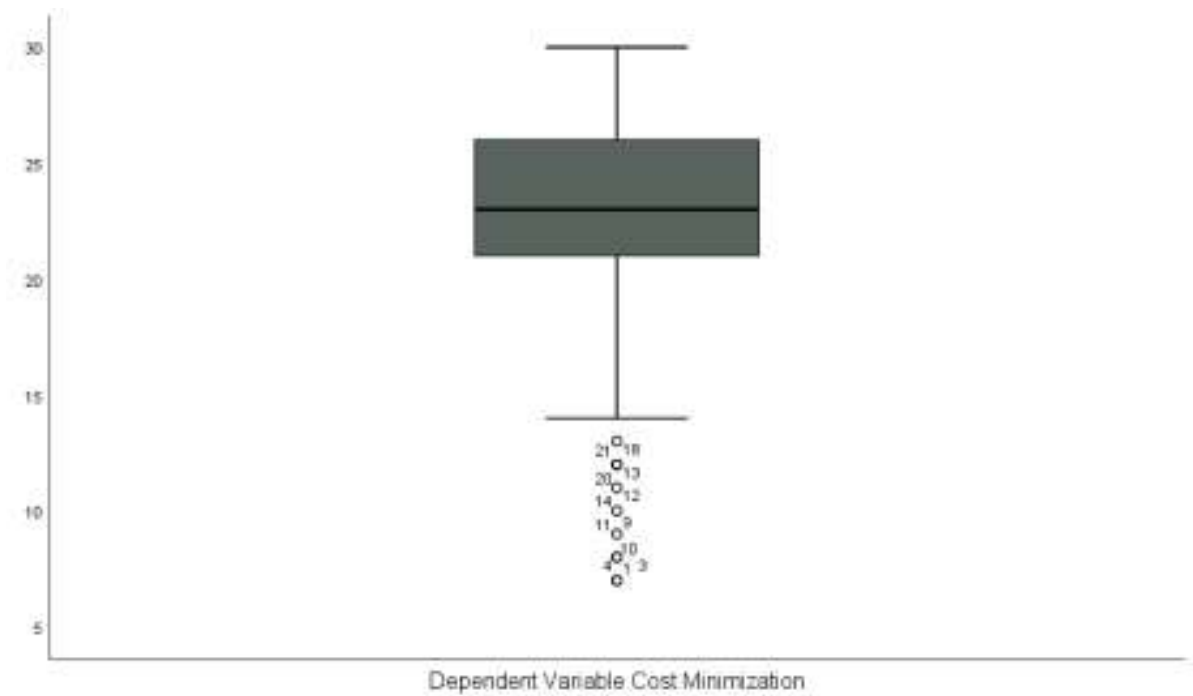

Figure 7.2

Source: Assumption Testing Result, 2022

Test for outliers for Waste Minimization

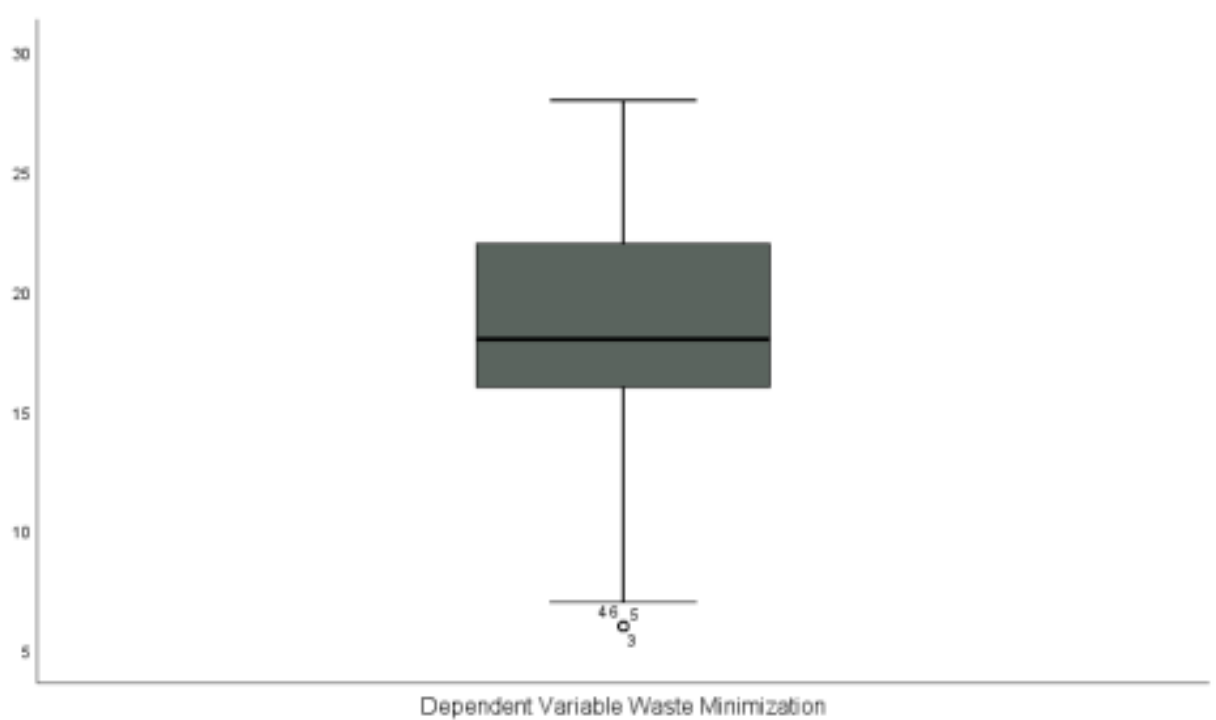

Figure 7.3

Source: Assumption Testing Result, 2022

\section{METHOD OF DATA ANALYSIS}

Karl Pearson's Product Movement Correlation Coefficient (R) was used to test the measures and the dimensions, referred to as variables through the software used in this study (SPSS Version 25. This is so, for the purpose of emphasis and confirmation of the reliability and validity assurances of the instrument used in the analyses, in making sure that findings from the analyses and the deductions from the findings were not misleading. There were 5 - point Rensis Likert scaling in this study. They were: Strongly Disagree (1), Disagree (2), Neutral (3), Agree (4) and Strongly Agree (5). The reading is scored according to the quality of attitude of the expressed by the research respondents. First of all, the five (5) Rensis Likert scaling of Strongly Disagree (1), Disagree (2), Neutral (3), Agree (4) and Strongly Agree (5) were added up, which summed up to give a total of fifteen (15); that is 
$1+2+3+4+5=15$. The sum of 15 was divided by five (5) items $(1,2,3,4$, and 5), which resulted to three (3) as the effect size of estimated average.

\section{DECISION RULE}

If the computed average of the opinions of the respondents on the univariate analysis was less than the estimated average, we rejected the overall opinion of the respondents. If, however the computed average of the opinions of the respondents was greater, was accepted as the general opinion of the research respondents. In each of the batches of the frequency table analysed, if twothird was accepted, then it was assumed that the overall opinions of the entire research respondents were accepted. If, otherwise rejected, the overall opinions of the entire research respondents were rejected. On the bivariate analysis, using the regression approach, if the significance of P-value was less than the predetermined the Alpha Coefficient value, then we rejected the null hypothesis. If the significance of P-value was greater than the predetermined the Alpha Coefficient value, we accepted the null hypotheses.

\section{THE UNIVARIATE ANALYSES BASED ON THE RESEARCH QUESTIONS}

(1) What relationship exists between Continuous Commitment and Resource Utilization of oil and gas companies in Port Harcourt, Rivers State, Nigeria?

On each research question, three sub-research questions, representing the relationship of each dimension to each of the measures posed to the respondents. If two-third of the sub-research questions were rejected, all three sub-research questions were assumed to have been rejected. A reverse conclusion was made when two-third was accepted.

Table 10.1 The mean response by the Research Respondents

\begin{tabular}{|c|c|c|}
\hline $\begin{array}{l}\text { Statist } \\
\text { Q1a G } \\
\text { worker }\end{array}$ & $\begin{array}{l}\text { d salaries } \\
\text { o save tir }\end{array}$ & $\begin{array}{l}\text { ot encourage } \\
\text { work }\end{array}$ \\
\hline $\mathrm{N}$ & Valid & 248 \\
\hline & Missing & 0 \\
\hline Mean & & 4.41 \\
\hline
\end{tabular}

Source: Research Survey, 2022

Table 10.2 Frequency Table of the Responses by the Research Respondents

Qla Good salaries do not encourage workers to save time at work

\begin{tabular}{llllll}
\hline & & & & Cumulative \\
& & Frequency & Percent & Valid Percent & Percent \\
\hline Valid & Strongly Disagree & 10 & 4.0 & 4.0 & 4.0 \\
& Disagree & 11 & 4.4 & 4.4 & 8.5 \\
& Neutral & 14 & 5.6 & 5.6 & 14.1 \\
& Agree & 46 & 18.5 & 18.5 & 32.7 \\
& Strongly Agree & 167 & 67.3 & 67.3 & 100.0 \\
& Total & 248 & 100.0 & 100.0 & \\
\hline & Accept & & \\
\hline
\end{tabular}

Source: Research Survey, 2022 
International Journal of Advances in Scientific Research and Engineering (ijasre), Vol 8 (2), February -2022

Interpretation of the Mean and Frequency Tables

From the responses of the research respondents, good pay leads to time minimization.

Null Hypothesis - $\mathrm{H}_{01}$ - There is no significant relationship between Continuous Commitment and Time minimization

Table 10.3

The mean response by the Research Respondents

\begin{tabular}{l} 
Statistics \\
\multicolumn{2}{l}{ Q1b Lack of alternative jobs } & do not \\
make workers achieve low \\
production cost
\end{tabular}

Table 10.4

Frequency Table of the Responses by the Research Respondents

Q1b Lack of alternative jobs do not make workers achieve low production cost

\begin{tabular}{|c|c|c|c|c|c|}
\hline & & Frequency & Percent & Valid Percent & $\begin{array}{l}\text { Cumulative } \\
\text { Percent }\end{array}$ \\
\hline \multirow[t]{6}{*}{ Valid } & Strongly Disagree & 8 & 3.2 & 3.2 & 3.2 \\
\hline & Disagree & 18 & 7.3 & 7.3 & 10.5 \\
\hline & Neutral & 16 & 6.5 & 6.5 & 16.9 \\
\hline & Agree & 32 & 12.9 & 12.9 & 29.8 \\
\hline & Strongly Agree & 174 & 70.2 & 70.2 & 100.0 \\
\hline & Total & 248 & 100.0 & 100.0 & \\
\hline
\end{tabular}

Source: Research Survey, 2022

Interpretation of the Mean and Frequency Tables

From the responses of the research respondents, when there are no alternative companies to work, there is an achievement to reduction of production cost.

Null Hypothesis $-\mathrm{H}_{02}$ - There is no significant difference in the relationship between Continuous Commitment and Cost minimization

Table 10.5

The mean response by the Research Respondents

Statistics
Q1c Cost of leaving the organization
$\begin{array}{ll}\text { does not leads to workers' reusing } \\
\text { materials }\end{array}$
\begin{tabular}{lll} 
N $\quad$ Valid & 248 \\
& Missing & 0 \\
Mean & & 4.21 \\
\hline
\end{tabular}
Source:

Table 10.6

Frequency Table of the Responses by the Research Respondents

Q1c Cost of leaving the organization does not lead to workers' reusing materials 
International Journal of Advances in Scientific Research and Engineering (ijasre), Vol 8 (2), February -2022

\begin{tabular}{llllll}
\hline & & & & Cumulative \\
& & Frequency & Percent & Valid Percent & Percent \\
\hline Valid & Strongly Disagree & 21 & 8.5 & 8.5 & 8.5 \\
& Disagree & 19 & 7.7 & 7.7 & 16.1 \\
& Neutral & 18 & 7.3 & 7.3 & 23.4 \\
& Agree & 18 & 7.3 & 7.3 & 30.6 \\
& Strongly Agree & 172 & 69.4 & 69.4 & 100.0 \\
& Total & 248 & 100.0 & 100.0 & \\
\hline & Decision & Accept & \\
\hline
\end{tabular}

Source: Research Survey, 2022

\section{Interpretation of the Mean and Frequency Tables}

From the responses of the research respondents, cost of leaving the existing company, leads to workers reusing company's materials.

Null Hypothesis - $\mathrm{H}_{03}$ - There is no significant relationship between Continuous Commitment and Waste Minimization

(2) What relationship exists between Normative Commitment and Resource Utilization in oil and gas companies in Port Harcourt, Rivers State, Nigeria?

Table $\mathbf{1 0 . 7}$

The Mean Response by the Research Respondents

\begin{tabular}{|c|c|c|}
\hline \multicolumn{3}{|c|}{$\begin{array}{l}\text { Statistics } \\
\text { Q2a Obligation of workers does not } \\
\text { compel workers to save time at } \\
\text { work }\end{array}$} \\
\hline \multirow[t]{2}{*}{$\overline{\mathrm{N}}$} & Valid & 248 \\
\hline & Missing & 0 \\
\hline Mean & & 1.98 \\
\hline
\end{tabular}

Table 10.8 Frequency Table of the Responses by the Research Respondents

Q2a Obligation of workers does not compel workers to save time at work

\begin{tabular}{llllll}
\hline & & & & Cumulative \\
& & Frequency & Percent & Valid Percent & Percent \\
\hline Valid & Strongly Disagree & 136 & 54.8 & 54.8 & 54.8 \\
& Disagree & 46 & 18.5 & 18.5 & 73.4 \\
& Neutral & 22 & 8.9 & 8.9 & 82.3 \\
& Agree & 23 & 9.3 & 9.3 & 91.5 \\
& Strongly Agree & 21 & 8.5 & 8.5 & 100.0 \\
& Total & 248 & 100.0 & 100.0 & \\
\hline \multicolumn{5}{c}{ Reject }
\end{tabular}

Source: Research Survey, 2022

Interpretation of the Mean and Frequency Tables

From the responses of the research respondents, obligation of the workers does not guaranty time minimization. 
International Journal of Advances in Scientific Research and Engineering (ijasre), Vol 8 (2), February -2022

Null Hypothesis $-\mathrm{H}_{04}$ There is no significant difference in the relationship between Normative Commitment and Time Minimization

Table 10.9

The mean response by the Research Respondents

\begin{tabular}{|c|c|c|}
\hline \multicolumn{3}{|c|}{$\begin{array}{l}\text { Q2b Contract terms are responsible } \\
\text { for workers achieving lowest } \\
\text { production cost }\end{array}$} \\
\hline $\bar{N}$ & Valid & 248 \\
\hline & Missing & 0 \\
\hline $\mathrm{Me}$ & & 1.89 \\
\hline
\end{tabular}

Table 10.10 Frequency Table of the Responses by the Research Respondents

Q2b Contract terms are responsible for workers achieving lowest production cost

\begin{tabular}{llllll}
\hline & & & & Cumulative \\
\hline Valid & Strongly Disagree & 150 & 60.5 & 60.5 & 60.5 \\
& Disagree & 42 & 16.9 & 16.9 & 77.4 \\
& Neutral & 16 & 6.5 & 6.5 & 83.9 \\
& Agree & 14 & 5.6 & 5.6 & 89.5 \\
& Strongly Agree & 26 & 10.5 & 10.5 & 100.0 \\
& Total & 248 & 100.0 & 100.0 & \\
\hline
\end{tabular}

Decision Reject

Source: Research Survey, 2022

\section{Interpretation of the Mean and Frequency Tables}

From the responses of the research respondents, adherence to contract terms does not lead to the achievement low production cost.

Null Hypothesis - $\mathrm{H}_{05}$ - There is no significant relationship between Normative Commitment and Cost Minimization

Table 10.11

The mean response by the Research Respondents

\begin{tabular}{lll}
\multicolumn{2}{c}{ Statistics } & \\
Q2c & Agreement & between \\
management and workers & leads to \\
workers' & reusing materials & \\
\hline N & Valid & 248 \\
& Missing & 0 \\
Mean & & 1.73 \\
\hline
\end{tabular}

Source: Research Survey, 2022

Table 10.12 Frequency Table of the Responses by the Research Respondents

Q2c Agreement between management and workers leads to workers' reusing materials 
International Journal of Advances in Scientific Research and Engineering (ijasre), Vol 8 (2), February -2022

\begin{tabular}{llllll}
\hline & & & & Cumulative \\
& & Frequency & Percent & Valid Percent & Percent \\
\hline Valid & Strongly Disagree & 172 & 69.4 & 69.4 & 69.4 \\
& Disagree & 26 & 10.5 & 10.5 & 79.8 \\
& Neutral & 14 & 5.6 & 5.6 & 85.5 \\
& Agree & 17 & 6.9 & 6.9 & 92.3 \\
& Strongly Agree & 19 & 7.7 & 7.7 & 100.0 \\
& Total & 248 & 100.0 & 100.0 & \\
\hline & Decision & \multicolumn{5}{c}{ Reject } \\
\end{tabular}

Source: Research Survey, 2022

\section{Interpretation of the Mean and Frequency Tables}

From the responses of the research respondents, agreement between management and workers does not lead to workers' reusing materials.

Null Hypothesis $-\mathrm{H}_{06}$ There is no significant relationship between Normative Commitment and Waste Minimization

(3) What relationship exists between affective commitment and resource utilization of oil and gas companies in Port Harcourt, Rivers State, Nigeria?

Table 10.13

The mean response by the Research Respondents

\begin{tabular}{|c|c|c|}
\hline \multicolumn{3}{|c|}{ Statistics } \\
\hline $\begin{array}{l}\text { Q3a } \\
\text { feeling }\end{array}$ & $\begin{array}{l}\text { orkers } \\
\text { o save tin }\end{array}$ & $\begin{array}{l}\text { emotional } \\
\text { work }\end{array}$ \\
\hline \multirow[t]{2}{*}{$\overline{\mathrm{N}}$} & Valid & 248 \\
\hline & Missing & 0 \\
\hline Mean & & 4.20 \\
\hline
\end{tabular}

Table 10.14 Frequency Table of the Responses by the Research Respondents

Q3a Workers need emotional feelings to save time at work

\begin{tabular}{|c|c|c|c|c|c|}
\hline & & Frequency & Percent & Valid Percent & $\begin{array}{l}\text { Cumulative } \\
\text { Percent }\end{array}$ \\
\hline \multirow[t]{6}{*}{ Valid } & Strongly Disagree & 12 & 4.8 & 4.8 & 4.8 \\
\hline & Disagree & 21 & 8.5 & 8.5 & 13.3 \\
\hline & Neutral & 23 & 9.3 & 9.3 & 22.6 \\
\hline & Agree & 41 & 16.5 & 16.5 & 39.1 \\
\hline & Strongly Agree & 151 & 60.9 & 60.9 & 100.0 \\
\hline & Total & 248 & 100.0 & 100.0 & \\
\hline Sourc & $\begin{array}{l}\text { Decision } \\
\text { Research Survey, 202 }\end{array}$ & & ccept & & \\
\hline
\end{tabular}

Interpretation of the Mean and Frequency Tables

From the responses of the research respondents, emotional feelings of the workers lead to time minimization. 
International Journal of Advances in Scientific Research and Engineering (ijasre), Vol 8 (2), February -2022

Null Hypothesis $-\mathrm{H}_{07}$ - There is no significant difference in the relationship between Affective Commitment and Time minimization

Table 10.15

The mean response by the Research Respondents

Statistics
\begin{tabular}{lll} 
Q3b Team work does not enable \\
lowest production cost \\
\hline N & Valid & 248 \\
& Missing & 0 \\
Mean & & 3.91 \\
\hline
\end{tabular}

Source: Research Survey, 2022

Table 10.16

Frequency Table of the Responses by the Research Respondents

Q3b Team work does not enable lowest production cost

\begin{tabular}{|c|c|c|c|c|c|}
\hline & & Frequency & Percent & Valid Percent & $\begin{array}{l}\text { Cumulative } \\
\text { Percent }\end{array}$ \\
\hline \multirow[t]{7}{*}{ Valid } & Strongly Disagree & 17 & 6.9 & 6.9 & 6.9 \\
\hline & Disagree & 41 & 16.5 & 16.5 & 23.4 \\
\hline & Neutral & 22 & 8.9 & 8.9 & 32.3 \\
\hline & Agree & 35 & 14.1 & 14.1 & 46.4 \\
\hline & Strongly Agree & 133 & 53.6 & 53.6 & 100.0 \\
\hline & Total & 248 & 100.0 & 100.0 & \\
\hline & Decision & & ccept & & \\
\hline
\end{tabular}

Source: Research Survey, 2022

Interpretation of the Mean and Frequency Tables

From the responses of the research respondents, team work leads to reduction of production cost.

Null Hypothesis - $\mathrm{H}_{08}$ - There is no significant relationship between Affective Commitment and Cost minimization

Table 10.17

The mean response by the Research Respondents

Statistics
$\begin{aligned} & \text { Q3c Management transparency does } \\
& \text { not encourage workers to reuse } \\
& \text { materials }\end{aligned}$
\begin{tabular}{lll} 
N & Valid & 248 \\
& Missing & 0 \\
Mean & & 4.44 \\
\hline
\end{tabular}

Source: Research Survey, 2022

Table 10.18

Frequency Table of the Responses by the Research Respondents 
International Journal of Advances in Scientific Research and Engineering (ijasre), Vol 8 (2), February -2022

\begin{tabular}{|c|c|c|c|c|c|}
\hline & & Frequency & Percent & Valid Percent & $\begin{array}{l}\text { Cumulative } \\
\text { Percent }\end{array}$ \\
\hline \multirow[t]{6}{*}{ Valid } & Strongly Disagree & 8 & 3.2 & 3.2 & 3.2 \\
\hline & Disagree & 16 & 6.5 & 6.5 & 9.7 \\
\hline & Neutral & 16 & 6.5 & 6.5 & 16.1 \\
\hline & Agree & 28 & 11.3 & 11.3 & 27.4 \\
\hline & Strongly Agree & 180 & 72.6 & 72.6 & 100.0 \\
\hline & Total & 248 & 100.0 & 100.0 & \\
\hline
\end{tabular}

Source: Research Survey, 2022

\section{Interpretation of the Mean and Frequency Tables}

From the responses of the research respondents, management transparency encourages workers to reuse materials.

Null Hypothesis $-\mathrm{H}_{09}$ - There is no significant relationship between Affective Commitment and Waste Minimization

The mean response by the Research Respondents

\section{BIVARIATE ANALYSES BASED ON THE NULL HYPOTHESES}

The hypotheses were analyzed, using multiple regression approach in three parts - Part1 $\left(\mathrm{Ho}_{1}, \mathrm{Ho}_{2}\right.$ and $\left.\mathrm{Ho}_{3}\right), \mathrm{Part}_{2}\left(\mathrm{Ho}_{4}, \mathrm{Ho}_{5}\right.$ and $\left.\mathrm{Ho}_{6}\right)$ and Part $3\left(\mathrm{Ho}_{7}, \mathrm{Ho}_{8}\right.$ and $\left.\mathrm{Ho}_{9}\right)$. Three tables were used to draw out the findings from the hypotheses testing - Summary Table, ANOVA Table and Coefficient Table.

\section{PART 1}

Null Hypothesis - Ho - There is no significant relationship between Continuous Commitment and Waste minimization

Null Hypothesis $-\mathbf{H o}_{2}$ - There is no significant relationship between Continuous Commitment and Cost Minimization

Null Hypothesis - $\mathbf{H o}_{3}$ - There is no significant relationship between Continuous Commitment and Time Minimization

Table 11.1

Model Summary Table for Continuous Commitment (CC) and Time Minimization (TM), Cost Minimization (CM), Waste Minimization (WM)

Model Summary

Std. Error Change Statistics

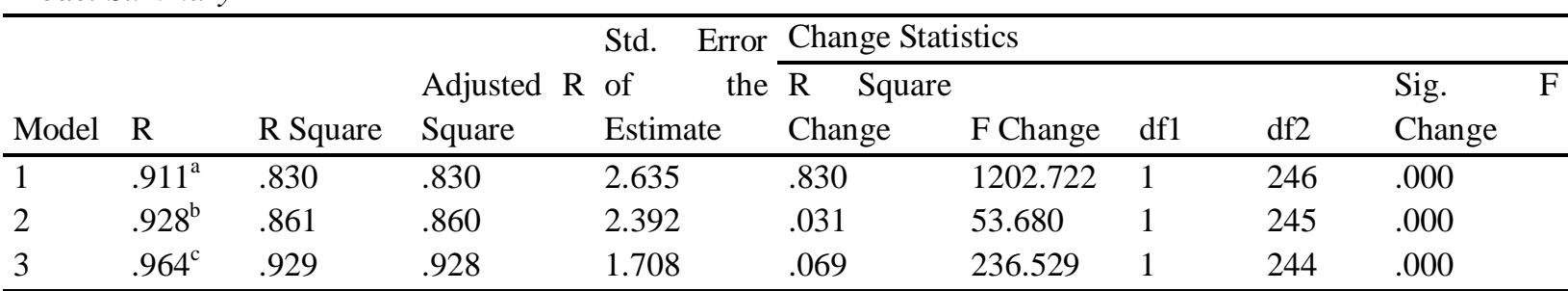

a. Predictors: (Constant), Dependent Variable Waste Minimization

b. Predictors: (Constant), Dependent Variable Waste Minimization, Dependent Variable Time Minimization

c. Predictors: (Constant), Dependent Variable Waste Minimization, Dependent Variable Time Minimization, Dependent Variable Cost Minimization

Source: Regression Analysis, 2022

Table 11.2 Analysis of the Variance (ANOVA) Table for Continuous Commitment (CC) and Time Minimization (TM), Cost Minimization (CM), Waste Minimization (WM) 
International Journal of Advances in Scientific Research and Engineering (ijasre), Vol 8 (2), February -2022

\begin{tabular}{lllllll}
\multicolumn{1}{l}{ ANOVA $^{a}$} & & & \\
\hline Model & & Sum of Squares & Df & Mean Square & F & Sig. \\
\hline 1 & Regression & 8353.049 & 1 & 8353.049 & 1202.722 & $.000^{\mathrm{b}}$ \\
& Residual & 1708.499 & 246 & 6.945 & & \\
& Total & 10061.548 & 247 & & & \\
\hline 2 & Regression & 8660.108 & 2 & 4330.054 & 756.981 & $.000^{\mathrm{c}}$ \\
& Residual & 1401.440 & 245 & 5.720 & & \\
& Total & 10061.548 & 247 & & & \\
\hline 3 & Regression & 9349.934 & 3 & 3116.645 & 1068.643 & $.000^{\mathrm{d}}$ \\
& Residual & 711.614 & 244 & 2.916 & & \\
& Total & 10061.548 & 247 & & & \\
\hline
\end{tabular}

a. Dependent Variable: Independent Variable Continuous Commitment

b. Predictors: (Constant), Dependent Variable Waste Minimization

c. Predictors: (Constant), Dependent Variable Waste Minimization, Dependent Variable Time Minimization

d. Predictors: (Constant), Dependent Variable Waste Minimization, Dependent Variable Time Minimization, Dependent Variable Cost Minimization

Source: Regression Analysis, 2022

Table 11.3

Coefficient Table for Continuous Commitment (CC) and Time Minimization (TM), Cost Minimization (CM), Waste Minimization (WM)

\begin{tabular}{|c|c|c|c|c|c|c|c|c|c|c|c|}
\hline \multirow[b]{2}{*}{ Mode } & & \multicolumn{2}{|c|}{$\begin{array}{l}\text { Unstandardized } \\
\text { Coefficients }\end{array}$} & \multirow[t]{2}{*}{$\begin{array}{l}\text { Standard } \\
\text { ized } \\
\text { Coefficie } \\
\text { nts }\end{array}$} & \multirow[b]{2}{*}{$\mathrm{T}$} & \multirow[b]{2}{*}{ Sig. } & \multicolumn{3}{|c|}{ Correlations } & \multicolumn{2}{|c|}{$\begin{array}{l}\text { Collinearity } \\
\text { Statistics }\end{array}$} \\
\hline & & B & $\begin{array}{l}\text { Std. } \\
\text { Error }\end{array}$ & & & & $\begin{array}{l}\text { Zero- } \\
\text { order }\end{array}$ & \multicolumn{2}{|l|}{ Partia } & \multicolumn{2}{|c|}{ Toleran } \\
\hline 1 & (Constant) & 8.170 & .684 & & $\begin{array}{l}11.94 \\
9\end{array}$ & .000 & & & & & \\
\hline & $\begin{array}{l}\text { Dependent } \\
\text { Variable Waste } \\
\text { Minimization }\end{array}$ & 1.236 & .036 & .911 & $\begin{array}{l}34.68 \\
0\end{array}$ & .000 & .911 & .911 & .911 & 1.000 & 1.000 \\
\hline 2 & (Constant) & 7.097 & .638 & & $\begin{array}{l}11.13 \\
1\end{array}$ & .000 & & & & & \\
\hline & $\begin{array}{l}\text { Dependent } \\
\text { Variable Waste } \\
\text { Minimization }\end{array}$ & .077 & .161 & .057 & .478 & .633 & .911 & .030 & .011 & .040 & 24.915 \\
\hline & $\begin{array}{l}\text { Dependent } \\
\text { Variable Time } \\
\text { Minimization }\end{array}$ & 1.214 & .166 & .872 & 7.327 & .000 & .928 & .424 & .175 & .040 & 24.915 \\
\hline 3 & $\begin{array}{l}\text { (Constant) } \\
\text { Dependent } \\
\text { Variable Waste } \\
\text { Minimization }\end{array}$ & $\begin{array}{l}3.698 \\
.391\end{array}$ & $\begin{array}{l}.506 \\
.117\end{array}$ & .288 & $\begin{array}{l}7.309 \\
3.336\end{array}$ & $\begin{array}{l}.000 \\
.001\end{array}$ & .911 & 209 & .057 & .039 & 25.694 \\
\hline & $\begin{array}{l}\text { Dependent } \\
\text { Variable Time } \\
\text { Minimization }\end{array}$ & -.439 & .160 & -.315 & - & .007 & .928 & -.173 & -.047 & .022 & 45.467 \\
\hline & $\begin{array}{l}\text { Dependent } \\
\text { Variable Cost } \\
\text { Minimization }\end{array}$ & 1.258 & .082 & .997 & $\begin{array}{l}15.38 \\
0\end{array}$ & .000 & .962 & .702 & .262 & .069 & 14.491 \\
\hline
\end{tabular}


a. Dependent Variable: Independent Variable Continuous Commitment

Source: Regression Analysis, 2022

Interpretation of Summary, ANOVA and Coefficient Tables in $\mathrm{Ho}_{1}, \mathrm{Ho}_{2}$ and $\mathrm{Ho}_{3}$ involving the relationship between Continuous Commitment (CC) and Waste Minimization (WM), Cost Minimization (CM), Time Minimization (TM)

The result of the Hierarchical Multiple Linear Regression Analysis (HMLRA) as revealed by the Summary, ANOVA and Coefficient tables above, which stood for the index formation for this analysis, the predictor variable, Continuous Commitment (CC) had a statistically significant relationship with the criterion variable, Resource Utilization (RU), but at different levels, represented by Waste Minimization (WM), Cost Minimization (CM) and Time Minimization (TM). From the Summary Model Table of $\mathrm{Ho}_{1}, \mathrm{Ho}_{2}$ and $\mathrm{Ho}_{3}$, the $\mathrm{R}^{2}$ value for WM, CM and $\mathrm{TM}=.929$. The prediction of WM, CM and TM, associated with this Hierarchical Multiple Regression Model (HMLRM) suggests that the CC accounted for $83.0 \%$ of the variation in the WM, 3.1\% in CM and 6.9\% in TM. This also suggested that $7.1 \%$ of the variation in WM, CM and TM could not be explained by CC. The Confidence Inter1val associated with this HMLRA is $95 \%$, which implies that Alpha Coefficient $=.05 ;$ Beta $=-.315, .997$ and $.288 ; \mathrm{t}=(7.309)-2.344,15.380$ and 3.336; F $(3,144,147)=1518.499,1533.970$ and 1068.643; B $(\mathrm{Y}-$ intercept $=3.698$, Slope $=-$ $.439,1.258$ and .391$)$; Tolerance $=.022, .069$ and $.039 ; \mathrm{VIF}=45.467,14.491$ and 25.694. There are no significant relationships

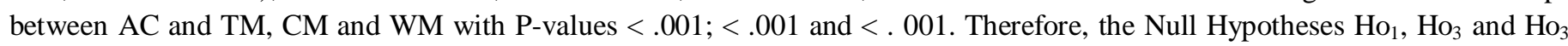
that stated that: $\mathrm{H}_{01}$ - There are no significant relationships between Continuous Commitment (CC) and Waste Minimization (WM); Continuous Commitment (CC) and Cost Minimization (CM); Continuous Commitment (CC) and Time Minimization (TM) were rejected and the Alternative Hypotheses $\mathrm{H} 1_{1}, \mathrm{H}_{2}$ and $\mathrm{H} 1_{3}$ that there are significant relationships between Continuous Commitment (CC) and Waste Minimization (WM); Continuous Commitment (CC) and Cost Minimization (CM); Continuous Commitment (CC) and Time Minimization (TM) be accepted.

\section{PART 2}

Null Hypothesis $-\mathbf{H o}_{4}$ - There is no significant difference in the relationship between Normative Continuous Commitment and Waste Minimization

Null Hypothesis - $\mathbf{H o}_{5}$ - There is no significant relationship between Normative Commitment and Cost Minimization

Null Hypothesis $-\mathbf{H o}_{6}$ - There is no significant relationship between Normative Commitment and Time Minimization

Table 11.4 Model Summary Table for Normative Commitment (NC) and Waste Minimization (WM), Cost Minimization (CM), Time Minimization (TM)

Model Summary

\begin{tabular}{|c|c|c|c|c|c|c|c|c|c|}
\hline \multirow[b]{3}{*}{ Model } & \multirow[b]{3}{*}{$\mathrm{R}$} & \multirow[b]{3}{*}{ R Square } & \multirow{3}{*}{$\begin{array}{l}\text { Adjusted } \mathrm{R} \\
\text { Square }\end{array}$} & \multirow{2}{*}{$\begin{array}{lr}\text { Std. } & \text { Error } \\
\text { of } & \text { the }\end{array}$} & \multicolumn{5}{|c|}{ Change Statistics } \\
\hline & & & & & Square & & & & Sig. \\
\hline & & & & Estimate & Change & F Change & df1 & df2 & Change \\
\hline 1 & $.737^{\mathrm{a}}$ & .543 & .541 & 3.876 & .543 & 292.250 & 1 & 246 & .000 \\
\hline 2 & $.781^{\mathrm{b}}$ & 609 & .606 & 3.590 & .067 & 41.740 & 1 & 245 & .000 \\
\hline 3 & $.897^{\mathrm{c}}$ & .804 & .802 & 2.548 & .195 & 242.439 & 1 & 244 & .000 \\
\hline
\end{tabular}

a. Predictors: (Constant), Dependent Variable Waste Minimization

b. Predictors: (Constant), Dependent Variable Waste Minimization, Dependent Variable Time Minimization

c. Predictors: (Constant), Dependent Variable Waste Minimization, Dependent Variable Time Minimization, Dependent Variable Cost Minimization

Source: Regression Analysis, 2022

Table 11.5 Analysis of the Variance (ANOVA) Table for Normative Commitment (AC) and Waste Minimization (WM), Cost Minimization (CM), Time Minimization (TM)

\begin{tabular}{lllllll}
\multicolumn{2}{l}{ ANOVA $^{a}$} & \multicolumn{1}{l}{} \\
\hline Model & & Sum of Squares & Df & Mean Square & F & Sig. \\
\hline 1 & Regression & 4391.225 & 1 & 4391.225 & 292.250 & $.000^{\mathrm{b}}$ \\
& Residual & 3696.287 & 246 & 15.026 & & \\
\hline
\end{tabular}


International Journal of Advances in Scientific Research and Engineering (ijasre), Vol 8 (2), February -2022

\begin{tabular}{lllllll}
\hline & Total & 8087.512 & 247 & & & \\
\hline 2 & Regression & 4929.286 & 2 & 2464.643 & 191.195 & $.000^{\mathrm{c}}$ \\
& Residual & 3158.227 & 245 & 12.891 & & \\
& Total & 8087.512 & 247 & & & \\
\hline 3 & Regression & 6503.333 & 3 & 2167.778 & 333.888 & $.000^{\mathrm{d}}$ \\
& Residual & 1584.179 & 244 & 6.493 & & \\
& Total & 8087.512 & 247 & & & \\
\hline
\end{tabular}

a. Dependent Variable: Independent Variable Normative Commitment

b. Predictors: (Constant), Dependent Variable Waste Minimization

c. Predictors: (Constant), Dependent Variable Waste Minimization, Dependent Variable Time Minimization

d. Predictors: (Constant), Dependent Variable Waste Minimization, Dependent Variable Time Minimization, Dependent Variable Cost Minimization

Source: Regression Analysis, 2022

Table 11.6 Coefficient Table for Normative Commitment (AC) and Waste Minimization (WM), Cost Minimization (CM), Time Minimization (TM)

Coefficients $^{a}$

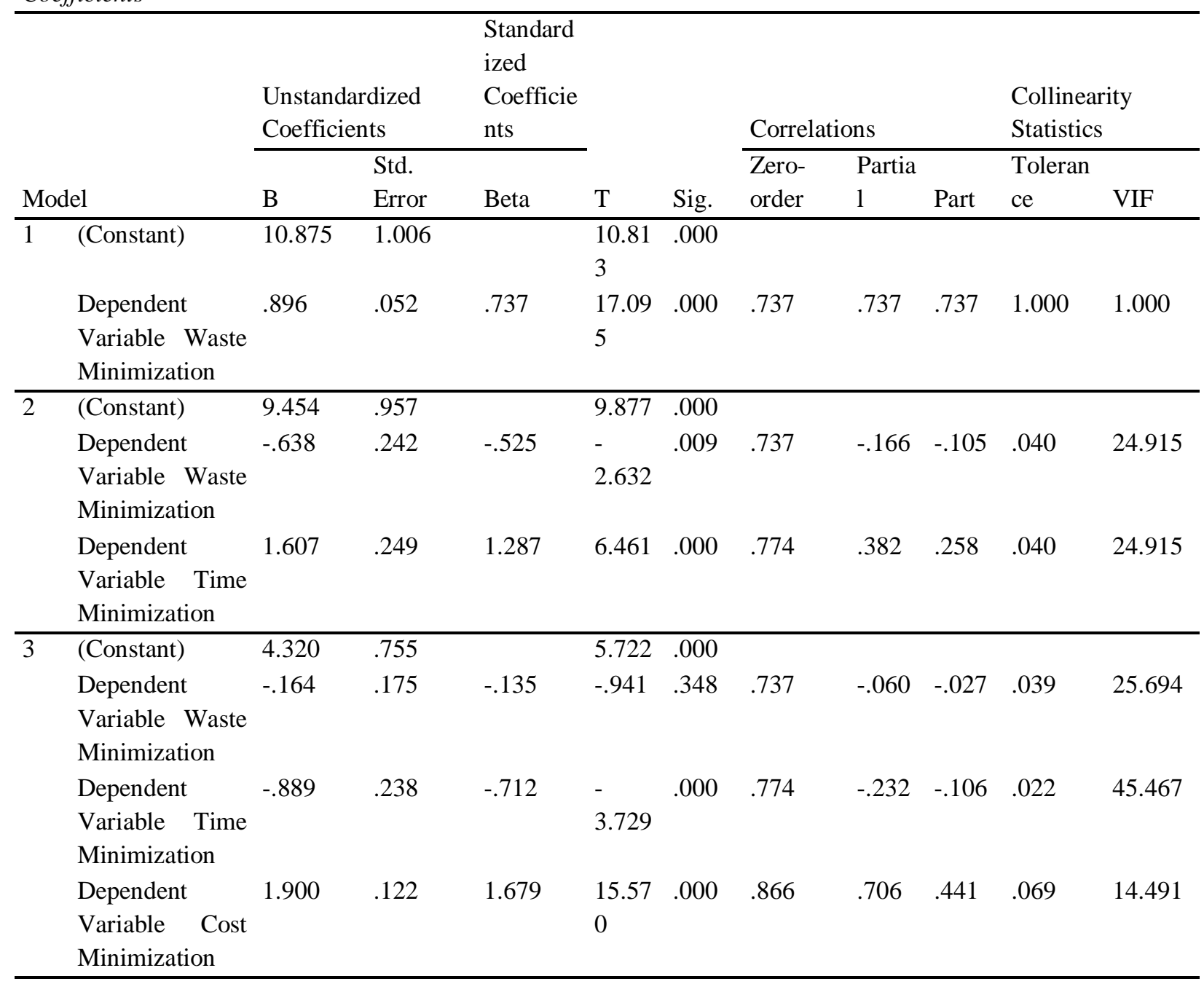

a. Dependent Variable: Independent Variable Normative Commitment

Source: Regression Analysis, 2022

Interpretation of Summary, ANOVA and Coefficient Tables in $\mathrm{Ho}_{4}, \mathrm{Ho}_{5}$ and $\mathrm{Ho}_{6}$ involving the relationship between Normative Commitment (NC) and Waste Minimization (WM), Cost Minimization (CM), Time Minimization (TM) 
The result of the Hierarchical Multiple Linear Regression Analysis (HMLRA) as revealed by the Summary, ANOVA and Coefficient tables above, which stood for the index formation for this analysis, the predictor variable, Normative Commitment (NC) had a statistically significant relationship with the criterion variable, Resource Utilization (RU), but at different levels, represented by Waste Minimization (WM) and Cost Minimization (CM) and Time Minimization (TM) in the model P-value < .001 at group level (ANOVA) and P-value $<.001, .001$ and P-value $=.348$, respectively at individual level. From the Summary Model Table of $\mathrm{Ho}_{4}, \mathrm{Ho}_{5}$ and $\mathrm{Ho}_{6}$, the $\mathrm{R}^{2}$ value for $\mathrm{CM}$, WM and $\mathrm{TM}=.804$. The prediction of $\mathrm{TM}$, CM and $\mathrm{WM}$, associated with this Hierarchical Multiple Regression Model (HMLRM) suggests that the CC accounted for 59.8\% of the variation in the TM, 20.5\% in CM and $0.1 \%$ in WM. This also suggested that $19.6 \%$ of the variation in TM, CM and WM could not be explained by CC. The Confidence Interval associated with this HMLRA is 95\%, which implies that Alpha Coefficient $=.05$; Beta $=-.712$, 1.179 and $-.135 ; \mathrm{t}=(5.722)-3.729,15.570$ and $-.941 ; \mathrm{F}(3,144,147)=366.628,500.622$ and 333.888; B $(\mathrm{Y}-$ intercept $=4.320$, Slope $=-.889,1.900$ and -.164$)$; Tolerance $=.022, .069$ and $.039 ;$ VIF $=45.467,14.491$ and 25.694. There are no significant relationships between $\mathrm{NC}$ and WM, CM with $\mathrm{P}$-value $<.001$ and $<.001$. Therefore, the Null Hypotheses $\mathrm{Ho}_{4}$, and $\mathrm{Ho}_{5}$ that stated that: There are no significant relationships between Normative Commitment (NC) and Waste Minimization (WM); Normative Commitment (NC) and Cost Minimization (CM) were rejected and the Alternative Hypotheses $\mathrm{H} 1_{4}$, and $\mathrm{H} 1_{5}$ that stated that there are significant relationships between Normative Commitment (NC) and Waste Minimization (WM); Normative Commitment (NC) and Cost Minimization (TM) were accepted. Conversely, there is a significant relationship between Normative Commitment $(\mathrm{NC})$ and Time Minimization (TM) with P-value $=.348$. Therefore, the Null Hypothesis $\mathrm{Ho}_{6}$ that stated that there is no significant difference in the relationship between Normative Commitment (NC) and Time Minimization (TM) was accepted.

\section{PART 3}

Null Hypothesis $-\mathbf{H o}_{7}-$ There is no significant difference in the relationship between Affective Commitment and Waste Minimization

Null Hypothesis - $\mathbf{H o}_{8}$ - There is no significant relationship between Affective Commitment and Cost Minimization

Null Hypothesis - $\mathbf{H o}_{9}$ - There is no significant relationship between Affective Commitment and Time Minimization

Table 11.7

Model Summary Table for Affective Commitment (AC) and Cost Minimization (CM), Waste Minimization (WM) and Time Minimization (TM)

Model Summary

\begin{tabular}{|c|c|c|c|c|c|c|c|c|c|}
\hline \multirow[b]{3}{*}{ Model } & \multirow[b]{3}{*}{$\mathrm{R}$} & \multirow[b]{3}{*}{ R Square } & \multirow{3}{*}{\multicolumn{2}{|c|}{$\begin{array}{l}\text { Std. Error } \\
\text { of the } \\
\text { Estimate }\end{array}$}} & \multicolumn{5}{|c|}{ Change Statistics } \\
\hline & & & & & Square & & & & Sig. \\
\hline & & & & & Change & F Change & df1 & $\mathrm{df} 2$ & Change \\
\hline 1 & $.757^{\mathrm{a}}$ & .574 & .572 & 3.653 & .574 & 330.987 & 1 & 246 & .000 \\
\hline 2 & $.793^{\mathrm{b}}$ & .629 & .626 & 3.415 & .055 & 36.548 & 1 & 245 & .000 \\
\hline 3 & $.873^{\mathrm{c}}$ & .762 & .759 & 2.742 & .133 & 136.055 & 1 & 244 & .000 \\
\hline
\end{tabular}

a. Predictors: (Constant), Dependent Variable Waste Minimization

b. Predictors: (Constant), Dependent Variable Waste Minimization, Dependent Variable Time Minimization

c. Predictors: (Constant), Dependent Variable Waste Minimization, Dependent Variable Time Minimization, Dependent Variable Cost Minimization

Source: Regression Analysis, 2022

Table. 11.8 Analysis of the Variance (ANOVA) Table for Affective Commitment (AC) and Cost Minimization (CM), Waste Minimization (WM) and Time Minimization (TM)

\begin{tabular}{lllllll}
\multicolumn{2}{l}{ ANOVA $^{a}$} \\
\hline Model & & Sum of Squares & df & Mean Square & F & Sig. \\
\hline 1 & Regression & 4416.803 & 1 & 4416.803 & 330.987 & $.000^{\mathrm{b}}$ \\
& Residual & 3282.709 & 246 & 13.344 & & \\
\hline
\end{tabular}


International Journal of Advances in Scientific Research and Engineering (ijasre), Vol 8 (2), February -2022

\begin{tabular}{lllllll}
\hline & Total & 7699.512 & 247 & & & \\
\hline 2 & Regression & 4842.934 & 2 & 2421.467 & 207.682 & $.000^{\mathrm{c}}$ \\
& Residual & 2856.578 & 245 & 11.660 & & \\
& Total & 7699.512 & 247 & & & \\
\hline 3 & Regression & 5865.553 & 3 & 1955.184 & 260.128 & $.000^{\mathrm{d}}$ \\
& Residual & 1833.959 & 244 & 7.516 & & \\
& Total & 7699.512 & 247 & & & \\
\hline
\end{tabular}

a. Dependent Variable: Independent Variable Affective Commitment

b. Predictors: (Constant), Dependent Variable Waste Minimization

c. Predictors: (Constant), Dependent Variable Waste Minimization, Dependent Variable Time Minimization

d. Predictors: (Constant), Dependent Variable Waste Minimization, Dependent Variable Time Minimization, Dependent Variable Cost Minimization

Source: Regression Analysis, 2022

Table 11.9 Coefficient Table for Affective Commitment (AC) and Cost Minimization (CM), Waste Minimization (WM) and Time Minimization (TM)

Coefficients $^{a}$

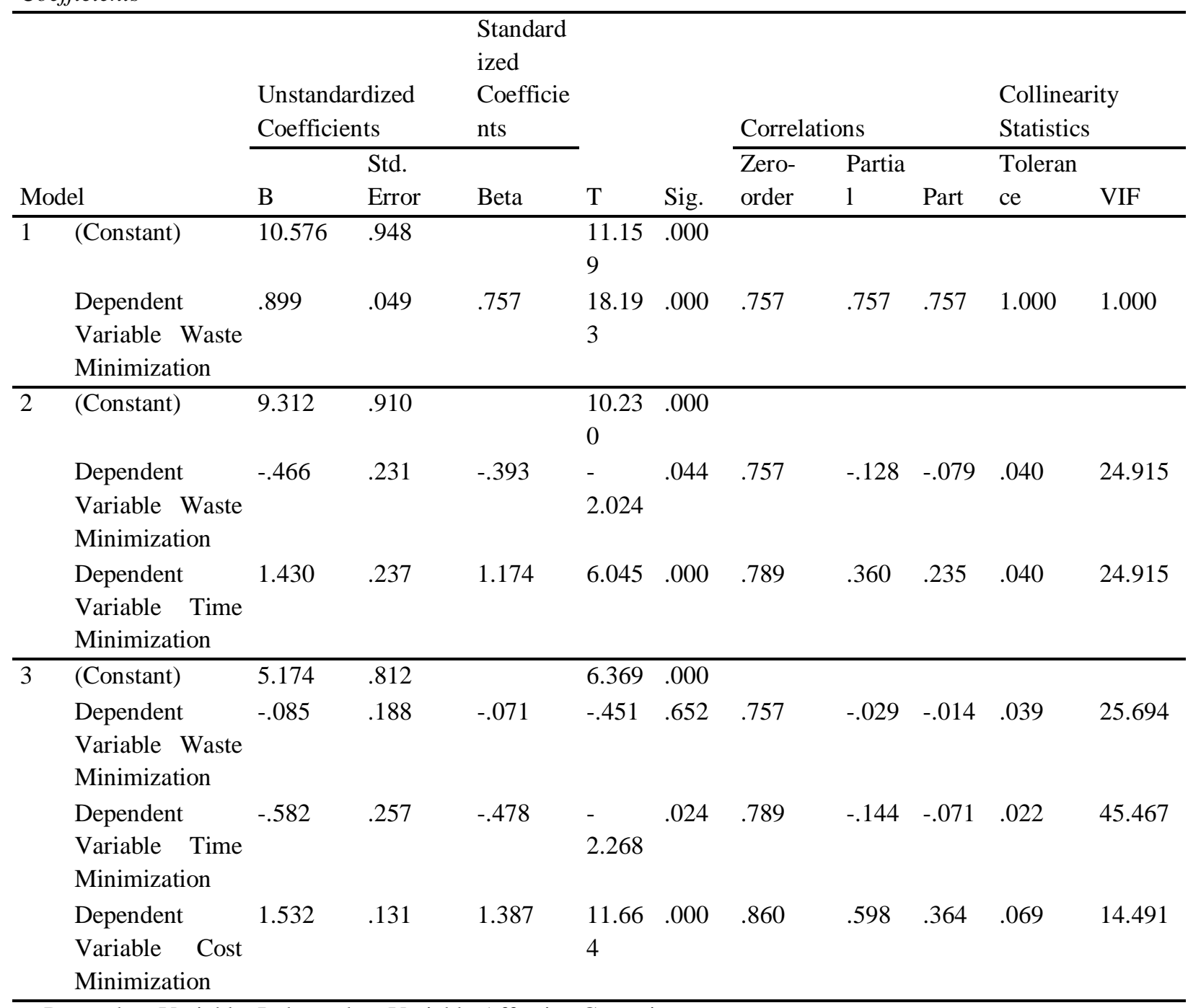

a. Dependent Variable: Independent Variable Affective Commitment

Source: Regression Analysis, 2022 
Interpretation of Summary, ANOVA and Coefficient Tables in $\mathrm{Ho}_{7}$, $\mathrm{Ho}_{8}$ and $\mathrm{Ho}_{9}$ involving the relationship between Affective Commitment (NC) and Time Minimization (TM), Cost Minimization (CM), Waste Minimization (WM)

The result of the Hierarchical Multiple Linear Regression Analysis (HMLRA) as revealed by the Summary, ANOVA and Coefficient tables above, which stood for the index formation for this analysis, the predictor variable, Affective Commitment (AC) had a statistically significant relationship with the criterion variable, Resource Utilization (RU), but at different levels, represented by Cost Minimization (CM) and Waste Minimization (WM), Time Minimization (TM) in the model P-value <.001 at group level (ANOVA) and P-value $=.024,<.001$ and P-value $=.652$, respectively at individual level. From the Summary Model Table of $\mathrm{Ho}_{7}, \mathrm{Ho}_{8}$ and $\mathrm{Ho}_{9}$, the $\mathrm{R}^{2}$ value for $\mathrm{TM}, \mathrm{CM}$ and $\mathrm{WM}=.762$. The prediction of TM, CM and WM, associated with this Hierarchical Multiple Regression Model (HMLRM) suggests that the AC accounted for 57.4\% of the variation in the WM, 5.5\% in TM and $13.3 \%$ in CM. This also suggested that $42.6 \%$ of the variation in TM, CM and WM could not be explained by AC. The Confidence Interval associated with this HMLRA is 95\%, which implies that Alpha Coefficient $=.05$; Beta $=-.478,1.387$ and $.071 ; \mathrm{t}=(6.639)-2.268,11.664$ and $-.451 ; \mathrm{F}(3,144,147)=330.987,307.682$ and 260.128; B $(\mathrm{Y}-$ intercept $=5.174$, Slope $=-$ $.582,-.071$ and 1.522); Tolerance $=.022, .069$ and $.039 ; \mathrm{VIF}=45.467,14.491$ and 25.694. There is a significant relationship between $\mathrm{AC}$ and WM, but no significant relationships between NC and CM, TM with P-value $=.652,<.001,<.001$, respectively. Therefore, the Null Hypotheses $\mathrm{Ho}_{7}$, and $\mathrm{Ho}_{8}$ that stated that: There are no significant relationships between Affective Commitment (AC) and Time Minimization (TM); Affective Commitment (AC) and Time Minimization (TM) was rejected and the Alternative Hypotheses $\mathrm{H}_{8}$, and $\mathrm{H} 1_{9}$ that stated that there are significant relationships between Affective Commitment (AC) and Cost Minimization (CM); Affective Commitment (AC) and Time Minimization (TM) was accepted. Conversely, the Null Hypotheses $\mathrm{Ho}_{7}$ that stated that there are no significant difference in the relationships between Affective Commitment (AC) and Waste Minimization (WM) was accepted.

\section{SUMMARY OF FINDINGS}

Table 12.1

This Table Summarized the Findings from the Univariate and Bivariate Analyses

\begin{tabular}{|c|c|}
\hline 1 & $\begin{array}{l}\text { There is a significant relationship between Continuous } \\
\text { Commitment }(\mathrm{CC}) \text { and Waste Minimization (WM) in oil and gas } \\
\text { industries in Port Harcourt, Nigeria }\end{array}$ \\
\hline 2 & $\begin{array}{l}\text { There is a significant relationship between Continuous } \\
\text { Commitment }(\mathrm{CC}) \text { and Cost Minimization }(\mathrm{CM}) \text { in oil and gas } \\
\text { industries in Port Harcourt, Nigeria }\end{array}$ \\
\hline 3 & $\begin{array}{l}\text { There is a significant relationship between Continuous } \\
\text { Commitment }(\mathrm{CC}) \text { and Time Minimization }(\mathrm{TM}) \text { in oil and gas } \\
\text { industries in Port Harcourt, Nigeria }\end{array}$ \\
\hline 4 & $\begin{array}{l}\text { There is a significant difference in the relationship between } \\
\text { Normative Commitment (NC) and Waste Minimization (WM) in } \\
\text { oil and gas industries in Port Harcourt, Nigeria }\end{array}$ \\
\hline 5 & $\begin{array}{l}\text { There is a significant relationship between Normative } \\
\text { Commitment (NC) and Cost Minimization }(\mathrm{CM}) \text { in oil and gas } \\
\text { industries in Port Harcourt, Nigeria }\end{array}$ \\
\hline 6 & $\begin{array}{l}\text { There is no significant relationship between Normative } \\
\text { Commitment (NC) and Time Minimization (TM) in oil and gas } \\
\text { industries in Port Harcourt, Nigeria }\end{array}$ \\
\hline 7 & $\begin{array}{l}\text { There is a significant difference in the relationship between } \\
\text { Affective Commitment (AC) and Waste Minimization (WM) in } \\
\text { oil and gas industries in Port Harcourt, Nigeria }\end{array}$ \\
\hline 8 & $\begin{array}{l}\text { There is a significant relationship between Affective } \\
\text { Commitment }(\mathrm{AC}) \text { and Cost Minimization }(\mathrm{CM}) \text { in oil and gas } \\
\text { industries in Port Harcourt, Nigeria }\end{array}$ \\
\hline 9 & $\begin{array}{l}\text { There is no significant relationship between Affective } \\
\text { Commitment }(\mathrm{AC}) \text { and Time Minimization }(\mathrm{TM}) \text { in oil and gas } \\
\text { industries in Port Harcourt, Nigeria }\end{array}$ \\
\hline
\end{tabular}

Source: Summary of Findings Table, 2022 


\section{DISCUSSION OF FINDINGS}

The discussion of the findings from this empirical work would be based on the subject of the research objectives. The results from the analyses showed that Resource Utilization (RU) was influenced by Employee Commitment (EC). For a clearer understanding of these findings, the authors delved into explaining what form of $\mathrm{EC} \mathrm{(AC,} \mathrm{CC,} \mathrm{and} \mathrm{NC)} \mathrm{controlled} \mathrm{what} \mathrm{form} \mathrm{of} \mathrm{RU} \mathrm{(TM,} \mathrm{CM}$ and $\mathrm{WM}$ ) and to what extent.

Objective 1 - The ascertainment of the relationship between Continuous Commitment (CC) and Resource Utilization (RU) in oil and gas companies in Port Harcourt, Rivers State, Nigeria.

The findings from the hypothesis $\mathrm{Ho}_{1}, \mathrm{Ho}_{2}$ and $\mathrm{Ho}_{3}$ bordering on the relationship that exists between Continuous Commitment (CC) and Waste Minimization (WM), Cost Minimization (CM) and Time Minimization (TM) in the oil and gas industry in Port Harcourt as attributable to the change in Continuous Commitment (CC). From our findings, there are three aspects of reality - the Summary table, which presents the present reality as influenced by the management within the oil and gas industry in Port Harcourt; the ANOVA Table, which presents the average reality based of the holistic behavior of the variables, and the Coefficient Table, which presents the ideal reality, that is, what ought to have been achieved, all things being equal in the industry under review.

In the current reality, managements of these companies target on CC to achieve $83.0 \%$ of WM and then, achieve $3.1 \%$ of $\mathrm{CM}$ and least of it is $6.9 \%$ of $\mathrm{TN}$ achieved. The authors observed on the current reality that workers in Nigeria thought these companies pay them highly, in consideration to the high level of joblessness, poverty and hunger in the land. According to Khartukov $\{14\}$, Nigerian oil and gas workers are the least paid, worldwide. From the findings, therefore, these oil and gas companies are exploiting the worker, taking advantage of very poor economy by using the workers to achieve WM. Workers also devote most of their time on their job to disadvantage of their families, loved ones, friends and relations, given the outcome of $6.9 \%$ variation in TM, accounted by CC. Prior to the COVID - 19 pandemic, $14 / 14$ or $7 / 7$ or $5 / 2$ work circles were observed. However, with the COVID - 19 pandemic, 35 days at work and 21 days off time or 21 days at work and 9 days off duty work circles were initiated.

In the average reality, the general assessment of interface between $\mathrm{CC}$ and $\mathrm{WM}, \mathrm{CM}$ and TM was significant. For the fact that the overall accountability of $\mathrm{CC}$ in the variability of WM, CM and TM was $92.9 \%$, ANOVA would give a blanket and umbrella assessment.

In the ideal reality, it was found out that in one unit of change of CC, CM changed 1.900 times. Similarly, in one unit of change in CC, WM changed -. 165 times. One unit change of CC, TM changed - .889 times. The order of preference in the outcomes in the interface of these variables is that cost minimization comes to the mind of the worker due to their supposed high reward in the organization. Ideally, if workers in the oil gas companies were paid as their counterpart outside the country, CM would be achieved. Should there be any sudden unexpected change in CC, the tolerant level of CM would be $6.9 \%$ as against $3.9 \%$ and $2.2 \%$ for WM and TM, respectively. There variations in the stability levels of AT, CM and WM. CM is the most stable

of the three with a Variant Inflation Factor (VIF) - 14.149, followed by WM - 25.694 and TM - 45.467. This view of CC having very important role in the time minimization, cost minimization and waste minimization within work operations is in tandem with the view of Farh $\{9\}$. When it comes to cost, Continuous commitment of the workers should be strongly considered. The following authorities sympathize with findings of this work - Bateman \& Strasser \{2\}, Zeb-Obipi \& Agada (27), Otamiri \& Odu $\{22\}$, Morrison \& Robinson $\{19\}$, Bateman \& Strasser (2), Lam, Pine \& Baum $\{14\}$ and Meyer \& Allen $\{17)$.

Objective 2 - The ascertainment of the relationship between Normative Commitment (NC) and Resource Utilization (RU) in oil and gas companies in Port Harcourt, Rivers State, Nigeria.

The findings from the hypothesis $\mathrm{Ho}_{4}, \mathrm{Ho}_{5}$ and $\mathrm{Ho}_{6}$ bordering on the relationship that exists between Normative Commitment (NC) and Waste Minimization (WM), Cost Minimization (CM) and Time Minimization (TM) in the oil and gas industry in Port Harcourt as attributable to the change in Continuous Commitment (CC). From our findings, there are three aspects of reality - the Summary table, which presents the present reality as influenced by the management within the oil and gas industry in Port Harcourt; the ANOVA Table, which presents the average reality based of the holistic behavior of the variables, and the Coefficient Table, which presents the ideal reality, that is, what ought to have been achieved, all things being equal in the industry under review. 
In the current reality, managements of these companies target on NC to achieve $54.3 \%$ of WM and then, $19.5 \%$ of TM achieved. The least achieved was 6.51 of CM. The authors observed on the current reality that managements of these companies use the instrumentality of adherence to company policies to make workers devote most of their time on their job to achieve WM. TM was also achieved by the means of strict policy adherence. CM was achieved in small measure due to the unwillingness of the workers on the work conditions, but compelled by the prevailing economic crunch.

In the average reality, the general assessment of interface between NC and WM, CM, TM was significant. For the fact that the overall accountability of NC in the variability of WM, CM and TM was 80.4\%, ANOVA would give a blanket and umbrella assessment.

In the ideal reality, it was found out that in one unit of change of NC, WM changed 1.532 times. Similarly, in one unit of change in NC, WM changed .-085 times. One unit change of NC, TM changed -.582 times. The explanation to this is that managements of the oil and gas companies also focus on NC to achieve CM. Company policies should be made strong, knowledgeable and compliable by all workers, if CM is to be achieved. At this point management should not expect workers to do the expected role. On the face of NC, workers are only expected to do the enacted role. Captions such as: "If you fail to do any of the company's policies, you have decided to leave the company" or "If you fail to do any of the company's policies, consequent management would follow". The order of preference in the outcomes in the interface between EC and RU, cost minimization comes to the mind of the worker due to the strong warning issued by the management. Should there be any sudden unexpected change in NC, the tolerant level of CM would be $6.9 \%$ as against $3.9 \%$ and $2.2 \%$ for WM and TM, respectively. There variations in the stability levels of AT, CM and WM. CM is the most stable of the three with a Variant Inflation Factor (VIF) - 14.149, followed by WM 25.694 and TM - 45.467. This view of NC having very important role in the time minimization, cost minimization and waste minimization within work operations is in tandem with the view of Farh $\{9\}$ and Mullins $\{19\}$. When it comes to cost minimization, Normative Commitment of the workers should be strongly considered.

\section{Objective 3 - The ascertainment of the relationship between Normative Commitment (NC) and Resource Utilization (RU) in oil and gas companies in Port Harcourt, Rivers State, Nigeria.}

The findings from the hypothesis $\mathrm{Ho}_{7}, \mathrm{Ho}_{8}$ and $\mathrm{Ho}_{9}$ bordering on the relationship that exists between Affective Commitment (AC) and Waste Minimization (WM), Cost Minimization (CM) and Time Minimization (TM) in the oil and gas industry in Port Harcourt as attributable to the change in Affective Commitment (AC). From our findings, there are three aspects of reality - the Summary table, which presents the present reality as influenced by the management within the oil and gas industry in Port Harcourt; the ANOVA Table, which presents the average reality based of the holistic behavior of the variables, and the Coefficient Table, which presents the ideal reality, that is, what ought to have been achieved, all things being equal in the industry under review.

In the current reality, managements of these companies target on AC to achieve $57.4 \%$ of WM and then, achieve 5.5\% of $\mathrm{CM}$, being the least achieved and $13.3 \%$ of TM. The authors observed on the current reality that workers devote most of their time on their job and less time with spent with families, loved ones, friends and relations. The factor behind workers behavior was the belief the no alternative job anywhere in Nigeria, high poverty rate and frustration everywhere within the shores of Nigeria. Through the policies imposed on them WM was realized.

In the average reality, the general assessment of interface between AC and WM, CM, TM was significant. For the fact that the overall accountability of AC in the variability of TM, CM and WM was 76.2\%, ANOVA would give a blanket and umbrella assessment.

In the ideal reality, it was found out that in one unit of change of AC, CM changed 1.532 times. Similarly, in one unit of change in AC, WM changed .085 times. One unit change of AC, TM changed -.582 times. In this ideal reality, if it found that, if management rewarded the workers, by international standards, CM would be achieved naturally. The order of preference in the outcomes in the interface of these variables is that cost minimization comes to the mind of the worker due to his/her sense of belongingness in the organization. Should there be any sudden unexpected change in AC, the tolerant level of CM would be $6.9 \%$ as against $3.9 \%$ and $2.2 \%$ for WM and TM, respectively. There variations in the stability levels of AT, CM and WM. Cm is the most stable of the three with a Variant Inflation Factor (VIF) - 14.149, followed by WM - 25.694 and TM - 45.467. This is a shared conclusion with some authors in literature - Bateman \& Strasser $\{2\}$ and Zeb-Obipi \& Agada $\{27\}$. However, impact of $\mathrm{AC}$ on $\mathrm{CM}$ was very strong, but quite weak on TM and even weaker on WM on individual relationship basis. On group relationship basis, that is when the worker has affection for the company and carrying out their duties, they focused on WM first, on the based company policy; TM and the least CM. The explanation to this is that each times the various managements of this oil 
and gas companies wanted to achieve $\mathrm{CM}$, focus should be on AC by way of making the workers have some sense of belonging with the organization through a better reward for the workers' services. This view of AC having very important role in the time minimization, cost minimization and waste minimization within work operations is in tandem with the view of Farh $\{9\}$. When it comes to cost minimization and waste minimization, affective commitment of the workers should be strongly considered.

\section{CONCLUSION}

This study, 'Employee Commitment and Resource Utilization in Oil and Gas Companies in Port Harcourt, Rivers State, Nigeria' probed into the relationship that exists between Employee Commitment and Resource Utilization. The study had Employee Commitment as its predictor variable with the dimensions: Continuous Commitment, Normative Commitment and Affective Commitment. It has Resource Utilization as its criterion variable with the measures: Waste Minimization, Cost minimization and Time Minimization. The objectives of the study were: (1) To ascertain the relationship between Continuous Commitment (CC) and Resource Utilization (RU) in oil and gas companies in Port Harcourt, Rivers State, Nigeria. (2) To ascertain the relationship between Normative Commitment (NC) and Resource Utilization (RU) in oil and gas companies in Port Harcourt, Rivers State, Nigeria. (3) To ascertain the relationship between Affective Commitment (AC) and Resource Utilization (RU) in oil and gas companies in Port Harcourt, Rivers State, Nigeria. An "Employee Commitment and Resource Utilization" questionnaire was used to source for data from the research respondents. A sample of 248 from a population of 650 extracted from workers from Shell Petroleum Development Company (SPDC), Elf Petroleum Nigeria Limited (ELF), Chevron Nigeria Limited and ExxonMobil. SPSS version 25 was used to do both univariate and bivariate analyses. The findings were that: (1) There is a significant relationship between Continuous Commitment (CC) and Waste Minimization (WM) in oil and gas industries in Port Harcourt, Nigeria. (2) There is a significant relationship between Continuous Commitment (CC) and Cost Minimization (CM) in oil and gas industries in Port Harcourt, Nigeria. (3) There is a significant relationship between Continuous Commitment (CC) and Time Minimization (TM) in oil and gas industries in Port Harcourt, Nigeria. (4) There is no significant difference in the relationship between Normative Commitment (NC) and Waste Minimization (WM) in oil and gas industries in Port Harcourt, Nigeria. (5) There is a significant relationship between Normative Commitment (NC) and Cost Minimization (CM) in oil and gas industries in Port Harcourt, Nigeria. (6) There is significant relationship between Normative Commitment (NC) and Time Minimization (TM) in oil and gas industries in Port Harcourt, Nigeria. (7) There is no significant difference in the relationship between Affective Commitment (AC) and Waste Minimization (WM) in oil and gas industries in Port Harcourt, Nigeria. (8) There is a significant relationship between Affective Commitment (AC) and Cost Minimization (CM) in oil and gas industries in Port Harcourt, Nigeria. (9) There is significant relationship between Affective Commitment (AC) and Time Minimization (TM) in oil and gas industries in Port Harcourt, Nigeria.

\section{RECOMMENDATION}

Following the findings from the empirical study, the researchers would put forth the following recommendations:

1. Oil and gas companies in Port Harcourt, Nigeria should target at employee commitment to achieve productive resource utilization.

2. Specifically, oil and gas companies in Port Harcourt, Nigeria should create sense of belonging to the workers to achieve waste minimization, cost minimization and time minimization at work.

3. Where there are strong policies adherences, with stiff consequence management, expected roles by the workers should not be expected.

4. The best option for the oil and gas companies in Port Harcourt is to make sure workers at all levels are well paid encourage continuous commitment of workers to achieve overall resource utilization.

\section{REFERENCES}

1 Ali, T. (2010). Optimization of resource utilization and project schedule through an object oriented simultation library. Institute of Constructive Informatics, TU Dresden, $\quad$ conference: 22 forum Bauinformatic. www.researchgate.net.

2 Bateman, T., \& Strasser, S. (2004). A longitudinal analysis of the antecedents of organizational commitment," Academy of Management Journal, 27(1), 95-112.

3 Becker, H. S. (1980). Notes on the concept of commitment. American Journal of Sociology, 66, 32 - 42. 
International Journal of Advances in Scientific Research and Engineering (ijasre), Vol 8 (2), February -2022

4 Bratton, J., \& Gold, J. (2007). Human resource management: Theory and practice, 4th Edition: Basingstoke, Palgrave Macmillan.

5 Brotterton, B, (2003). International hospitality industry: Structure, characteristics and issues. New York, ButterworthHeinemann.

6 Cambridge Rindge and Latin School Research Guide (2019). Writing an Introduction. http://www.crlsresearchguide.org/17_Writing_Introduction.asp

7 Cely, P. (2011).Organization theory and design: Singapore, Info Access \& Distribution Limited.

8 Duggan, O. (2011). Corporate culture and organizational effectiveness. New York: Wiley publications.

9 Farh, C.C. \& Seo, T. (2012). Emotional intelligence, teamwork effectiveness, \& job performance: The moderating role of job context. Journal of Applied Psychology, 80 (4), 60-82.

10 Freund, A., \& Carmeli, A. (2003).An empirical assessment: Reconstruct model for five universal forms of work commitment," Journal of Managerial Psychology, 18(7), 708-725.

11 Gaertner, S. (2009).Structural determinants of job satisfaction and organizational commitment in turnover models. Human Resource Management Review, 9(4), 479-493.

12 Herzberg, F., Mausner, B., \& Snyderman, B. (2009).The motivation to work: New York, Wiley Printing Press.

13 Huczynski, A., \& Buchanan, D. (2007).Organizational behavior: An introductory text," 6th Edition: Harlow, Pearson/Prentice Hall.

14 Lam, T., Pine, R., \& Baum, T. (2003). Subjective norms: Effectives on job satisfaction. Annals of Tourism Research, 30(1), 160-177.

15 Maduabuchi, C. R. (2020). Organizational culture and corporate performance of commercial banks in Port Harcourt, Rivers state. ( Unpublished doctoral dissertation ). Ignatius Ajuru University of Education Rumuolumiri Port Harcourt Rivers State.

16 Meyer, J.P., \& Allen, N. J. (1997). Commitment in the work-place: Theory, research, and application. Thou-sand Oaks, Sage Publication Limited.

17 Meyer, J. P., \& Allen, N. J. (2010).A three-component conceptualization of organizational commitment. Human Resource Management Review, 1(1), 61-89.

18 Mullins, L. J. (2001). Hospitality management and organizational behavior," 4th Edition: Harlow, Pearson/Longman Press.

19 Morrison, E. W., \& Robinson, S, L. (1997). When employees feel betrayed: A model of how psychological contract violation develops," Academy of Management Review, 22(1), 226-256.

Morrow, P. C. (2003).The theory and measurement of work commitment: Greenwich, JAI Press.

20 Mowday, R. T., Richard, M., Steers \& Porter, L. W. (1979).The measurement of organizational commitment. Journal of Vocational Behaviour, 14, 224 - 247.

21 Schwepker, C. H. (2001). Ethical climate's relationship to job satisfaction, organizational commitment, and turnover intention in the sales force," Journal of Business Research, 54, 39-52.

22 University of Southern California (USC) Guide (2019). Organizing your research paper: 4. USCLibraries. http://libguides.usc.edu/writingguide/introduction

23 Zeb-Obipi, I., \& Maduabuchi, C. E. (2020). How innovation culture affects corporate performance: A literature review. Nigeria Journal of Management Sciences, 22, (1), 49-50. 
24 Zeb-Obipi, I., \& Agada, J. T. (2018). Workplace social programmes and employee commitment: A literally reflection. Journal of Business and Management ( IOSR-JBM). 20, (1), 09-16.

25 Zeb-Obipi, I. (2015). Corporate productivity performance. A harmonist framework: International journal of Business and General Management, 1 (4), 19-25.

Authors: Maduabuchi, Chinyere Emeka ${ }^{1}$; Simeon, Abel Igah ${ }^{2}$

Contacts: chinyereemeka10@gmail.com

brotherabel1@gmail.com 